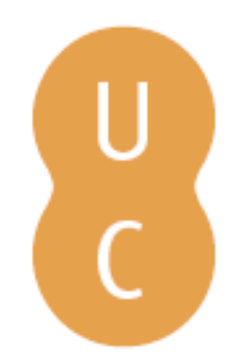

\title{
pommalina
}

\section{Cooperation and competition in argumentative exchanges}

\author{
Autor(es): $\quad$ Krabbe, Erik C. W.
}

Publicado por: Imprensa da Universidade de Coimbra

URL

persistente: URI:http://hdl.handle.net/10316.2/31998

DOI: $\quad$ DOI:http://dx.doi.org/10.14195/978-989-26-0498-5_6

Accessed : $\quad$ 26-Apr-2023 11:41:11

A navegação consulta e descarregamento dos títulos inseridos nas Bibliotecas Digitais UC Digitalis, UC Pombalina e UC Impactum, pressupõem a aceitação plena e sem reservas dos Termos e Condições de Uso destas Bibliotecas Digitais, disponíveis em https://digitalis.uc.pt/pt-pt/termos.

Conforme exposto nos referidos Termos e Condições de Uso, o descarregamento de títulos de acesso restrito requer uma licença válida de autorização devendo o utilizador aceder ao(s) documento(s) a partir de um endereço de IP da instituição detentora da supramencionada licença.

Ao utilizador é apenas permitido o descarregamento para uso pessoal, pelo que o emprego do(s) título(s) descarregado(s) para outro fim, designadamente comercial, carece de autorização do respetivo autor ou editor da obra.

Na medida em que todas as obras da UC Digitalis se encontram protegidas pelo Código do Direito de Autor e Direitos Conexos e demais legislação aplicável, toda a cópia, parcial ou total, deste documento, nos casos em que é legalmente admitida, deverá conter ou fazer-se acompanhar por este aviso.

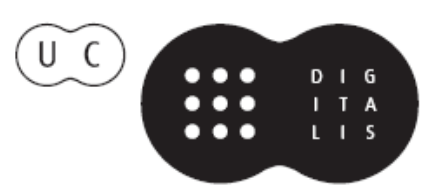




\title{
RHETORIC AND ARGUMENTATION IN THE BEGINNING OF THE XXIst CENTURY
}

\author{
EDITED BY
}

Henrique Jales Ribeiro
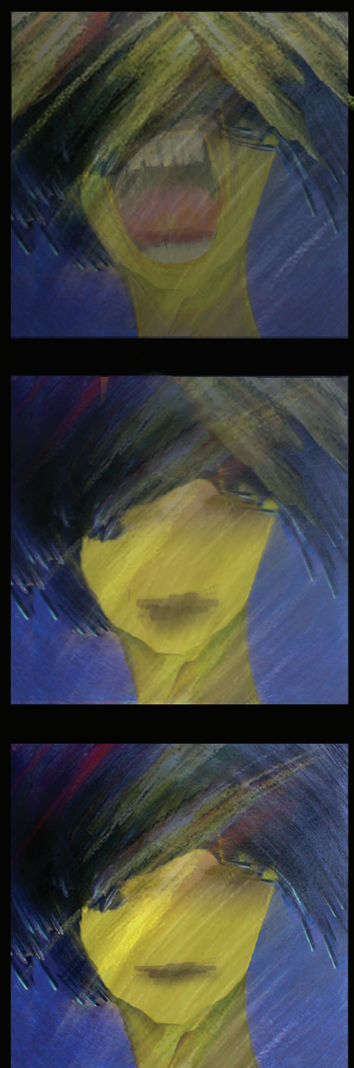
(Página deixada propositadamente em branco) 


\title{
RHETORIC AND ARGUMENTATION IN THE BEGINNING OF THE XXIst CENTURY
}

\author{
EDITED BY
}

Henrique Jales Ribeiro

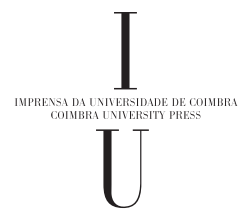

- COImbra 2009 
COORDENAÇÁO EDITORIAL

Imprensa da Universidade de Coimbra

Email: imprensauc@ci.uc.pt

URL: http://www.uc.pt/imprensa_uc

Vendas online: http://siglv.uc.pt/imprensa/

CONCEPÇÃO GRÁFICA

António Barros

CAPA

José Luís Madeira (IA / FLUC)

PRÉ-IMPRESSÁO

Paulo Oliveira

[PMP]

EXECUÇĂO GRÁFICA

Sereer, Soluçóes Editoriais

ISBN

978-989-8074-77-5

Depósito LEGAL

???????????????????????

OBRA PUBLICADA COM A COLABORAÇĀO DE:

\title{
FCT Fundação para a Ciência e a Tecnologia
}

MINISTÉRIO DA CIÊNCIA, TECNOLOGIA E ENSINO SUPERIOR Portugal

\author{
s \\ Ciência.Inovaçã̃o Programa Operacional Ciência e Inovação 2010 \\ 2010 MINISTÉRIO DA CIÊNCIA, TECNOLOGIA E ENSINO SUPERIOR \\ Unidade I\&D | Linguagem, Interpretação E Filosofia \\ ๑ JULHO 2009, IMPRENSA DA UNIVERSIDADE DE COIMBRA
}




\title{
CHAPTER 6 \\ COOPERATION AND COMPETITION IN ARGUMENTATIVE EXCHANGES
}

\author{
Erik C. W. Krabbe*
}

\begin{abstract}
Cooperation and competition are two aspects of argumentative exchanges that are amply illustrated in Plato's dialogues. Since the days of Aristotle two corresponding trends are present in argumentation theory. One trend is to see argumentation as a common enterprise in which both parties in a dialogue cooperate to produce good arguments; the other is to see argumentation as a contest in which both parties compete to let their own arguments prevail.-This paper purports to clarify the way these two trends are to be understood. It discusses Aristotle's approach in Topics 8 as well as contemporary contributions from formal dialectic and pragmadialectics. It is pointed out that the opposition between cooperative and competitive aspects of argumentation should not be confused with that between a normative and a descriptive approach or that between rhetorical and dialectical aspects.-It will be argued that both trends should be taken into account when constructing a normative model for argumentation. There are several ways in which this could be achieved: (i) the cooperative and the competitive aspects could be assigned to different types of dialogue; (ii) one of the aspects could be subordinated to the other; (iii) both aspects could be reconciled to coexist in separate compartments of one type of dialogue.
\end{abstract}

\section{INTRODUCTION}

When arguments are presented there must be an arguer (or arguers), whether this be a person, or a group of persons, or some institution. Unless the argument is meant for the rocks and the streams, there must also be an addressee (or addressees), again a

\footnotetext{
* University of Groningen, Oude Boteringestraat 52, 9712 GL Groningen, The Netherlands. Professor Emeritus of Logic and Philosophical Theory of Argumentation.

E-mai: E.C.W.Krabbe@rug.nl
} 
person or a - perhaps only vaguely denoted - group of persons, or some institution. Hopefully, for the arguer, there are also some receivers of the argument: these need not include all or even any of the addressees, but may include these and moreover some others: those listening in. When the receivers react to the argument, either by accepting it or by advancing questions, objections, or even counterarguments, there is an argumentative exchange. ${ }^{1}$ Usually such exchanges occur, besides other kinds of exchanges, in a context of discussion, dialogue, or debate.

Now, an argumentative exchange is something for which neither the arguer nor the receiver who reacts to the argument (the respondent) is exclusively responsible. It is something they construct together. In this sense there can be no doubt that arguer and respondent do cooperate. But cooperation in argumentative exchanges goes much further. For one thing, general pragmatic principles, such as Grice's Cooperative Principle, apply to argumentative exchanges as much as to other forms of communication. Also, most often there is some further goal or purpose shared by an arguer and a respondent, ranging from understanding the contents of their exchange, to agreement, resolution of differences, joint action, and attaining the truth. Thus, in the extreme, arguer and respondent are in no way opposed, but peacefully and serenely building up the arguments that will help them reach their common goals in full harmony. Such "cooperative argumentation" is sometimes strongly preferred over "competitive argumentation" because the former constitutes an "approach to disagreement ... [that] is a process of reasoned interaction intended to help participants and audiences make the best assessments or the best decisions in any given situation" (Makau and Marty 2001: 87). It is the type of argumentation for which Daniel Cohen (1995: 186) introduced the metaphor of a barn raising gathering.

But then, argument is war. About this other metaphor, Cohen wrote that it:

... manages to permeate to all corners of our discourse about arguments and our argumentation practice. We routinely speak, for example, of knockdown, or even killer, arguments and powerful counterattacks, of defensible positions and winning strategies, and of weak arguments that are easily shot down while strong ones have a lot of punch and are right on target. (1995: 178, original emphasis)

In his paper, Cohen recognized the dangers of this metaphor and argues for other metaphors. But in the end he deems it unlikely "that any single metaphor can fit all the shapes that arguments take or serve all the purposes that arguments serve" (1995: 187). This includes the barn raising metaphor.

But even if the war metaphor may be dangerous and needs to be replaced by other metaphors, that doesn't mean that it doesn't have a point. Besides cooperation, there is this other side of argumentative exchanges, which shows them to be antagonistic and even adversarial. The arguer wants to convince the addressee; the addressee, if she receives the message, may respond in order to resist the message. From this some altercation may ensue. Even if both parties do abide by shared rules of discussion

\footnotetext{
${ }^{1}$ To be precise: argumentative exchanges may also precede the argument, for instance when a prospective addressee asks for an argument or when a prospective arguer asks an addressee to grant a premise.
} 
their interaction may be highly competitive, given that both have interests at stake and prefer the issue to be resolved in their own favor. But a resolution in favor of one party excludes one in favor of the other because, as Aristotle says, "then [if parties are merely competing against one another] they cannot both reach the same goal, since more than one cannot be victorious" (Top. 8.11, 161a39-b1). ${ }^{2}$

In this paper these two trends, which are clearly to some extent at odds, will be further scrutinized. After a short discussion of their appearance in Plato's dialogues (Section 2), it will be seen how they fare in Aristotle's theorizing (Section 3), and in contemporary dialectic (Section 4). This will lead to some observations about dialectical models and ways these may incorporate and reconcile both trends (Section 5).

\section{PLATONIC ROOTS}

The cooperative and competitive aspects or trends of argumentative exchanges are clearly present in Plato's dialogues. The competitive strain is evident in the earlier dialogues, most prominently in the Euthydemus, where each questioner tries to trip up his interlocutor in order to refute him. It is true that, in the Euthydemus, the metaphors used when reflecting on the argumentative conversation are not those of war, but they are all the same those of a wrestling match (Euthydemus $277 \mathrm{~d}, 288 \mathrm{a})$. The audience laughs and cheers when they see a respondent biting the dust (Euthydemus 276b, 303b). The cooperative strain is dominant in the later dialogues, where the questioner (Socrates, the Athenian, or the stranger) exerts control over the direction of the conversation and an extremely cooperative, or even subservient, respondent volunteers mostly affirmative answers ("Yes, Socrates", "Of course, Socrates").

In Plato's Protagoras (334c-338e) the issue of competitiveness versus cooperativeness appears as the underlying motive for negotiations about the rules of discussion among the discussants themselves (Socrates, Protagoras, Callias, Alcibiades, Critias, Prodicus, and Hippias). At face value, these negotiations constitute a discussion at a meta-level concerned with procedural matters (Krabbe 2002, 2003); but Jonathan Lavery, who carefully analyzed the passage, has pointed out that what is really at issue in these negotiations "is the prior ethical disagreement about the nature of the discussion the participants are engaged in: Is it a competitive debate or a collaborative conference" (Lavery 2007: 5, original emphasis). When Socrates succeeds getting his interlocutors to agree upon some impartial, non-partisan standards of discourse, ${ }^{3}$ the essence of this "victory" is not, as commonly supposed, that Socrates has forced Protagoras to conform to Socrates' preferred way of arguing (by questions and short answers):

\footnotetext{
${ }^{2}$ Quotations from the Topics are taken from the translation by E. S. Forster (Aristotle 1976).

${ }^{3}$ Summarized in Krabbe 2002: 37: "The outcome of these negotiations is the following: the discussion will proceed in the dialectic rather than the rhetorical mode; both parties will take turns as Questioner and as Answerer; Protagoras will be the first Questioner; the audience as a whole will act as chairmen; if Protagoras does not stick to the question in his replies, Socrates and the audience will ask him 'not to ruin the conversation' (this sanction may have been more severe than we appreciate)" (338c-e).
} 
Socrates' real "victory", so to speak, in securing this outcome consists in elevating the discussion from that of a contest to that of a collaborative venture. Yet it remains a collaboration in which all the participants fulfill their function by maintaining a critical posture towards each other. (Lavery 2007: 11, original emphasis)

Lavery concludes that:

... the message underlying Protagoras is... that in a properly constituted conference discussion will proceed as a conversation in which all the participants respect impartial standards of discourse. (Lavery 2007: 13, original emphasis)

Thus the discussants settle for a mode of discussion that is essentially cooperative, but also competitive in as far the participants "fulfill their function by maintaining a critical posture toward each other". This critical, competitive aspect is borne out by the further development of the dialogue.

The concept of a cooperative mode of discussion, with competitive aspects, developed in Plato's Protagoras, corresponds to - and may lie at the root of - Aristotle's notion of dialectical discussion, to which we turn in the next section.

\section{THE EIGHTH BOOK OF THE TOPICS: CONCEALMENT AND A COMMON TASK}

In the eighth book of the Topics Aristotle discusses dialectical procedure, giving instruction for both questioners and respondents. The book is somewhat puzzling, as it seems to shift between competitive and cooperative conceptions of argumentative discussion. One difficulty for the modern reader is that Aristotle presupposes familiarity with a kind of discussion we are no longer familiar with in daily life. The constitutive rules of these discussions are nowhere systematically expounded. Nevertheless we know some of the essentials, such as there being two roles: the Questioner (Arguer) and the Answerer (Respondent). The Questioner proposes a problem for discussion (e.g., "Is virtue teachable, or not?"); the Answerer selects a thesis to uphold (an answer to the problem). The contradictory of this thesis, is sometimes called the thesis of the Questioner, it is the conclusion the Questioner is to deduce. In order to do so, the Questioner asks the Answerer to grant certain premises. It is not upon the Answerer to defend his thesis by argument; only the Questioner is to defend his. If the Questioner succeeds, the Answerer is said to have been refuted. This brief sketch may suffice. ${ }^{4}$

At first sight, this way to arrange argumentative discussions seems to favor the competitive view of arguments. This impression gets confirmation from Aristotle's discussion of concealment (krupsis), that is: the tactics to be used to keep the Answerer ignorant about the way the Questioner intends to go about reaching his conclusion, thereby refuting the Answerer (Topics 8.1). Why would one keep one's interlocutor

\footnotetext{
${ }^{4}$ The sketch is a bit misleading in its simplicity: premises can also be established by induction, analogy, or a preliminary deduction. So the argument a Questioner builds up may be quite complex. Further, the answerer may present objections, and thus become an arguer himself.
} 
ignorant about the way one's argument is going? Why must the conclusion be established by surprise? From an entirely cooperative point of view, this cannot be understood. However, according to Aristotle, premises 'which are used for concealment are for contentious [i.e., eristic] purposes; but, since this kind of proceeding is always directed against another party, these also must be employed' (Topics 8.1, 155b2628).

Aristotle goes on (Topics 8.1, 156a7-157a5) to recommend some astounding tactics for the Questioner to avoid that his argument be spoiled by an untimely discovery of the plot. If you are a Questioner you should, for instance, complicate your reasoning by deducing also the premises (as many as possible) of the ultimate deduction of your thesis; you should, however, refrain from disclosing your conclusions beforehand (leaving your interlocutor in confusion about what you are up to), but deduce them later, in one fell swoop; you should ask for various premises shifting from one part of the argument to another, in order to avoid asking consecutively for premises that are to be linked to reach a conclusion and thus giving away what this conclusion will be; when asking for some proposition to be granted you should keep the Answerer in the dark about whether you need this proposition itself or its contradictory for your argument; to quench suspicions, you should once in a while raise an objection against your own argument; when proposing a premise, you should stress that it conforms to what is generally accepted, and therefore should be admitted; you should not be too eager to get your premise admitted, for thus you may arouse resistance; you should ask for the premise you need most at the end, since most people start denying at the beginning but more easily admit things later; however, with some difficult Answerers this is the other way round: they get more and more reluctant to concede anything, so with these people you should ask for this premise at the beginning; you should prolong your argument and introduce irrelevant points, thus covering up what is wrong. Some of these tactics are also listed in the Sophistical Refutations (Ch. 15), together with some others, such as that you should go fast, to prevent people from seeing where you are heading, and that you should try to incense the Answerer so as to make him less attentive. Perhaps these latter tactics are only meant for purely competitive (contentious, eristic) discussions - which Aristotle does not really champion -, but the ones listed in Topics 8.1 seem rather intended for a kind of dialectic interchange of which Aristotle approves and that is at the focus of his interest (dialectic proper, one might say). We must conclude that a number of tactical recommendations about concealment apply both to eristic discussions and to dialectic proper, and that this latter kind of discussion has some competitive (contentious, eristic) features.

In Topics 8.5, this latter kind of discussions is clearly set apart from purely contentious (eristic) discussions as well as from didactic discussions, which seem to be conceived of as purely cooperative. It is the kind of discussion of those concerned with exercise, examination (peirastic), or inquiry. ${ }^{5}$ Its cooperative character becomes

5 These types of discussion correspond to those that are implied by the four kinds of arguments used in discussion distinguished in Sophistical Refutations 2: didactic (or demonstrative) arguments, dialectical arguments (in a narrower sense), examination-arguments (peirastic arguments), and contentious arguments (eristic arguments). Peirastic is described as a department of dialectic (Soph. Ref. 8, 169b25; 11, 
apparent in various passages. For instance, the rules for the Answerer Aristotle expounds in the same chapter (8.5) actually require the Answerer to assist the questioner in constructing a good argument, and thus to contribute to his own refutation, if such a refutation by good argument is feasible. A good argument, according to Aristotle, starts from premises that are more acceptable and more familiar than its conclusion. Marta Wlodarczyk (2000: 156) has dubbed this principle the Overarching Principle (OP). ${ }^{6}$ Following this principle, a good Questioner must ask for premises that are more acceptable than the conclusion he is to prove. But, according to the rules in Topics 8.5, not only the Questioner, but also the Answerer, is to guard the quality of the argument in this respect: if the Questioner asks for a premise that fails to be more acceptable than the conclusion to be reached by him, the Answerer should not concede it. On the other hand, the Answerer should concede any premise than is more acceptable that the conclusion to be reached by the Questioner. ${ }^{7}$

The cooperative side of dialectic gets a terse expression when Aristotle talks about a common task (koinon ergon). At least part of this common task must consist of constructing good arguments, conforming to the Overarching Principle (Wlodarczyk 2000: 167). But not every Answerer is as cooperative as one would wish:

... often the person questioned is the cause of the argument not being properly discussed, because he does not concede the points which would have enabled the argument against his thesis to have been properly carried out; for it is not within the power of one party only to ensure the proper accomplishment of the common task. It is, therefore, necessary sometimes to attack the speaker and not the thesis, when the answerer is on the watch for points against the questioner and also employs abuse. By behaving peevishly, then, people make their discussions contentious instead of dialectical. (Topics 8.11, 161a17-24)

Difficult ("peevish") behavior by one party makes it necessary to use contentious (eristic) means even in a predominantly cooperative dialectical discussion. Here these means (ad hominem attacks against a speaker) may go even beyond the tactics of concealment. They are directed at a difficult Answerer, but not only the Answerer can misbehave:

171b4-5). Cf. Krabbe and Van Laar 2007: 37, where a reference to Topics 8.5 would have strengthened our point of view.

${ }^{6}$ The rules in Topics 8.5 are analyzed in Wlodarczyk 2000: Section 2. In her article Wlodarczyk argues both for the competitive and for the cooperative nature of dialectic on the basis of a careful analysis of various passages.

7 These rules are given for three different situations, determined by whether the thesis of the Answerer is unacceptable, acceptable or neither. For the first situation Aristotle stipulates what the Answerer should not concede, for the others what he should concede. In the first case it may be understood that other premises should be conceded and in the second case that other premises should not. Cf. Wlodarczyk 2000: 159, who, after stating the rule for the first case, writes: "In other words, the answerer should concede, as Aristotle goes on to say (159b13-14), those premisses which are endoxa and more endoxa than the conclusion...". I agree that this may be implied, but do not find Aristotle saying so explicitly. 
Now in business he who hinders the common task is a bad partner, and the same is true in argument; for here, too, there is a common purpose, unless the parties are merely competing against one another; for then they cannot both reach the same goal, since more than one cannot be victorious. It makes no difference whether a man acts like this in his answers or in his questions; for he who asks questions in a contentious spirit and he who in replying refuses to admit what is apparent and to accept whatever question the questioner wishes to put, are both of them bad dialecticians. (Topics 8.11, 161a37-161b5)

Aristotle may denounce the contentious (eristic) spirit; even so such tactics remain a necessary element of dialectic. In the earlier quotation we saw how this gives us a way to handle a contentious interlocutor. One may doubt whether reacting in a contentious way oneself would indeed be the right way to go about such cases (should one react to a fallacy by a fallacy?). But leaving this issue aside, we also saw that contentious tactics, such as those of concealment, were deemed necessary 'since this kind of proceeding is always directed against another party' (Topics 8.1, 155b2627). This other party need not even be difficult (peevish) to make these contentious tactics appropriate.

What we have found can be summed up as follows:

(1) Aristotle recognizes contentious (eristic) discussions; they are purely competitive. $^{8}$

(2) Some contentious tactics should also be used in dialectical discussions proper, especially, but not exclusively, when one is confronted by a difficult interlocutor.

(3) The core business of these dialectical discussions, however, consists in the cooperative construction of good arguments.

(4) Possibly, didactic (demonstrative) discussions between a teacher and a student were conceived of as purely cooperative.

Thus we find that there are contexts where argument is competitive (eristic discussions) and where it is cooperative (didactic discussions), whereas in dialectical discussions proper it is both. In the latter case one may, moreover, expect that the competitive features will not thwart, but rather further the cooperative accomplishment of the common task. As Wlodarczyk writes:

It seems... that the desire to win, as long as it is subordinated to the desire to accomplish the common task, would not hinder good dialectic. Moreover, assuming the dialecticians pursue the common task, the desire to win could be seen as a stimulus for pursuing it better than the opponent and hence for achieving the best argument for a given conclusion. (Wlodarczyk 2000: 170, note 41)

\footnotetext{
${ }^{8}$ Except that even contentious discussions must be cooperative in as far as they constitute an interaction.
} 


\section{NEW KINDS OF DIALECTIC}

After having discussed these ancient conceptions of dialectic, I want to inspect some of the new kinds of dialectic that have come forward the last fifty years, to see how they are positioned with respect to the issue of cooperation versus competition. We shall first consider formal dialectical approaches and then turn to pragma-dialectics. The New Dialectic (Walton and Krabbe 1995; Walton 1998), in which the degree of cooperativeness depends upon the type of dialogue, will be considered in Section 5.

\subsection{Formal Dialectic}

The year 1958 was a remarkable year for the theory of argumentation. I do not need to remind you of the seminal works by Toulmin and by Perelman and Olbrechts-Tyteca, whose fiftieth anniversary is celebrated at this conference. But 1958 was also the year of birth of a new kind of dialectic that was ultimately to become part of the stock-in-trade of argumentation theory. I'm referring to Paul Lorenzen's introduction of dialogue logic at a conference in Venice, where he read his paper Logik und Agon [Logic and agon (= contest)]. ${ }^{9}$ In Logik und Agon, which was a paper about logic rather than theory of argumentation, Lorenzen sharply contrasted the agonistic roots of logic, with the solo-minded and monolectical points of view of the logicians of his time. Stressing the roots of logic in ancient dialectic, he wrote:

If one compares this agonistic origin of logic with modern conceptions, according to which logic is the system of rules that, whenever they are applied to some arbitrary true sentences, will lead one to further truths, then it will be but too obvious that the Greek agon has come to be a dull game of solitaire. In the original two-person game only God, secularized: "Nature", who is in possession of all true sentences, would still qualify as an opponent. Facing Him there is the human individual - or perhaps the individual as a representative of humanity - devoted to the game of patience: starting from sentences that were, so he believes, obtained from God before, or snatched away from Him, and following rules of logic, he is to gain more and more sentences. (Lorenzen and Lorenz 1978: 1; translation ECWK.)

Dialogue logic, in contradistinction to semantic and inferential approaches to logic, starts from a dialectical situation. There are two parties, called "Proponent" and "Opponent", roughly corresponding to the Questioner and the Answerer in ancient dialectical discussions. The Proponent has a thesis to defend; the Opponent attacks the Proponent's thesis, but has no thesis of his own to defend. The Opponent, however, makes concessions - either initially or following upon the Proponent's questioning - that

\footnotetext{
9 This paper, published as Lorenzen 1960, remained rather unknown until it was republished in Lorenzen and Lorenz 1978. Until then, the best-known early paper on dialogue logic had been Lorenzen 1961.
} 
the Proponent may use to defend his thesis. Systems of dialogue logic (dialogue games) are defined by stipulating sets of rules that completely determine the possible moves in each situation in each kind of game. On the basis of such games one can define concepts of logical validity, but that is not our present concern. Rather, we are concerned with the significance of Lorenzen's move for the study of argumentation. In fact, Lorenzen started bridging the gap between logic and argumentation theory by introducing into logic two roles and a difference of opinion, as well as rules to resolve the difference, and thus brought logic half-way to meet the interests of theory of argumentation.

Clearly, in dialogue logic great store is set by the competitive side of discussion. Winning and losing are basic notions in dialogue logic. The same holds for attempts to reformulate and justify rules of dialogue logic as rules of a model of argumentation. Such an attempt was undertaken, about thirty years ago by Else Barth and myself (Barth and Krabbe 1982: Ch. 3, 4). That there should be opportunities for winning and losing was obvious:

Why should the debaters enter into a discussion at all? There must be some possible - spiritual, if not material - immediate results, desired by the debater in question. (Barth and Krabbe 1982: 71)

The quoted passage is followed by rules that introduce formal winning and losing, stipulating precisely when a party must admit that the other has won or may claim that the other has lost, with careful instructions to recognize the rationality of the means used by the other, when doing so. If you have won and the other has lost, your reward consists in your interlocutor's admission that this is the case, and in your right to proclaim so. If you have lost and the other has won, your punishment consists in your duty to admit that this is the case and the right of the other to proclaim so. The stakes may not seem excessively high, yet it may be clear from this example that Barth and I wanted to highlight the concepts of winning and losing, appreciating the value of competitive behavior for what we called a "resolution of conflicts of avowed opinions".

In contemporary theory of argumentation the appreciation of competition and controversy differs. There seems more appreciation of cooperative than of competitive argumentation as a normative theory. ${ }^{10}$ What is certain, however, is that the issue of whether to go for competition or for cooperation, is not an issue about the descriptive versus the normative. It is simply not true that though in real life argument may be competitive, our norms all endorse the cooperative point of view. On the one hand, there is real cooperation in real life; on the other hand, some norms endorse the competitive point of view, as we saw to be the case with norms of formal dialectic.

But even so, formal dialectic is not in every respect and always on the competitive side. Some cooperation, of course, is needed to play the game. Moreover there are other kinds of formal dialectic than the one inspired by Lorenzen. In fact, the term "formal dialectic" was not even used by Lorenzen; it has been introduced by Charles

${ }^{10}$ A balanced view has been presented by Trudy Govier 1999. 
Hamblin (1970). In Hamblin's systems of formal dialectic winning or losing a game is not the point. Consequently these systems cannot be used to define concepts of validity, which make logicians sad. But, of course such systems can be used as models for argumentative exchanges. These then, are models that do more adhere to the cooperative than to the competitive point of view but nevertheless provide strictly formal dialectic rules for specific interactions. Thus systems of formal dialectic may emphasize either point of view.

\subsection{Pragma-Dialectics}

Nowadays there are two versions of pragma-dialectics: the older standard version (Van Eemeren and Grootendorst 1984, 2004) and the newer, integrated version (Van Eemeren and Houtlosser 1999, 2002). I shall first discuss the standard version. ${ }^{11}$ In critical discussion - the normative model put forward by pragma-dialecticians - the principal goal is to reach a resolution of a difference of opinion. A resolution is not just a consensus, let alone a settlement or an agreement to disagree. According to Van Eemeren and Grootendorst (2004: 58) a "difference of opinion is only resolved if a joint conclusion is reached on the acceptability of the standpoints at issue on the basis of a regulated and unimpaired exchange of arguments and criticism." ${ }^{12}$ As in formal dialectic systems, there are two parties or roles: the Protagonist and the Antagonist. These have different tasks but share the same goal of resolving their difference of opinion, a goal that reminds one of Aristotle's common task. Thus one may expect a high level of cooperation between the two parties. Indeed, they are sometimes asked to make some decisions together, for instance when, in the concluding stage, they have to determine the outcome of the discussion. ${ }^{13}$ Yet, not all competitive features are absent. It may be that the pragma-dialecticians do not speak of winning a discussion, but they speak of resolving a difference in one's favor, a difference having been resolved in favor of the Protagonist if the parties are, ultimately, in agreement that his standpoint is acceptable (and the Antagonist's doubt must be retracted) and in favor of the Antagonist if they are, ultimately, in agreement that the standpoint of the Protagonist must be retracted (Van Eemeren and Grootendorst 2004: 61-62). On close inspection, this concept of getting an issue resolved in one's favor is similar in function to what formal dialecticians mean by 'winning a discussion' and indicates a competitive aspect of critical discussion. The general set-up of critical discussion and the division of labor between the Protagonist and the Antagonist point in the same direction. In the standard version of pragma-dialectics, therefore, the cooperative

\footnotetext{
11 Though the integrated version supersedes the standard version, the latter remains important, both historically and as representing the normative kernel of the standard version.

${ }^{12}$ It is probably to stress this interpretation of "resolution" that pragma-dialecticians now speak of "resolution on the merit".

13 "The discussants close the discussion together by determining the final outcome" (Van Eemeren and Grootendorst 2004: 154). One may wonder whether this could lead to another critical discussion. About this and other problems of the concluding stage, see Krabbe 2007.
} 
point of view may be dominant, but both the competitive and the cooperative point of view are represented.

In the integrated version, the concept of resolving an issue in one's favor has been brought more into prominence. Thus the competitive features of argumentative exchanges have been emphasized. These features, which were not (or not sufficiently) taken into account in the standard version, are characterized as rhetorical aspects. However, as we saw, competitiveness and competitive tactics have always been part of dialectics. Rhetoric, on the other hand, is conceived by some as not primarily competitive but as concerned with communication or "identification" (Burke 1950), or as "a perspective we take to examine all the ways by which meaning is created symbolically among people" (Wenzel 1987: 106). In the epideictic genre competition between the rhetor and his audience seems even totally absent.

These observations lead to three remarks. First, the competitive features that the integrated theory wants to take into account need not always be characterized as rhetorical; they can often be characterized as dialectical (or they could be characterized as both). Ultimately, this is only a matter of an adequate choice of terms. Yet I think it would be an infelicitous choice, if it leads to the consequence that dialectic will be completely robbed of its competitive dimension. ${ }^{14}$ Second, since rhetoric can be not only competitive but also cooperative and dialectic can be not only cooperative but also competitive, the issue of whether to go for competition or for cooperation is not to be construed as an issue about rhetoric versus dialectic. Third, in the integrated version of pragma-dialectics both the cooperative and the competitive point of view are represented; the competitive point of view gets more emphasis than in the standard version, but the cooperative point of view retains normative priority.

\section{COOPERATION AND COMPETITION IN NORMATIVE MODELS}

Having skimmed through old and new dialectic and having noted how they fare where cooperation and competition are at issue, one may ask what would be the best way to go about the construction of normative models for argumentative exchanges. That a certain minimal cooperativeness is needed - since otherwise there can be no exchange at all - remains undisputed. Something more is perhaps needed to assure that the exchange is communicative. But should cooperativeness be kept down to this minimum? To attain this minimum, which assures communication, it would suffice to have some Gricean rules. Following these rules, arguments may be understood and be adequately reacted to. Normative models usually have further aspirations, such as that the discussants should behave rationally and respect rules about such matters as burden of proof and relevancy. The pragma-dialectical model provides a good example of a model that urges this wider concept of cooperativeness. But is this enough? Should cooperativeness remain restricted to "playing the rational game"? Or should

\footnotetext{
${ }^{14}$ See, for a motivation to use the term "rhetorical", Van Eemeren and Houtlosser 2002: 135, note 13. For a more extensive discussion, see also Krabbe 2004.
} 
it even go further, as we saw when reading Aristotle, who actually suggested that the Answerer should assist the Questioner in trying to construct the best possible argument? If cooperation should go that far, one might go on to ask whether one should have any competition at all in argumentative discussions.

These questions cannot be answered once and for all. Much depends on what one is constructing the model for; what the theorist is trying to achieve. I shall, however, present some considerations and make some suggestions.

The situations in which argumentative exchanges are most useful are those in which there is some difference of opinion, say about what is the case or what should be done. For dialogue logic and for pragma-dialectics this is the initial situation. By common standards, this situation is not optimal. For, presumably, in an optimal situation the parties would be in agreement. Arguments are called in as a means to change the situation into a better situation. A normative model for argumentation is to give us directions about how to do this. But since the initial situation is not optimal, a normative model cannot just describe optimal transitions from one optimal situation to another. It must take suboptimal situations into account. And in order to be useful, normative models must not only take into account the suboptimality of the initial situation, but also the cognitive and situational limitations, as well as the motivations, of arguers and respondents that are to make the moves towards a better situation. That is, normative models must take into account that discussants are limited in their reasoning capacity and susceptible to fallacious reasoning; that they are usually each committed to a particular point of view and susceptible to prejudice; and that they are each motivated by a desire to win in a context of controversy. Thus, I see the task of the theorist not (or not merely) as that of finding out what discussants should do in ideal circumstances, but rather as that of giving some directions about what to do when there are cognitive limitations, when one may be confronted by fallacies, prejudice, and controversy, and when both sides are eager to win. What should discussants, ideally, do in such not so ideal circumstances when trying to resolve their differences of opinion?

Partial answers would be that the reasoning should proceed by small steps that all concerned can follow; that it must be possible to challenge fallacious moves and prejudices; that there should be a division of labor assigning to each arguer the task to defend his point of view; and that there should be opportunities for winning and losing. The division of labor may by itself give an opportunity for competition. In realistic normative models, competition is moreover motivated by the desire to win, this being a reality that can better be taken into account.

Another consideration - which we meet at the end of Section 3 - is that allowing competitiveness to be part of the procedure may be instrumental to good dialectic, that is: it may further the construction of better arguments and hence the attainment of a resolution of the difference of opinion on the merit.

So some competitiveness should be incorporated in normative models. It is not so clear, however, how much this should be, or - seen from the other side - how much cooperation a normative model should prescribe. Must the Answerer (the Antagonist) actually help the Questioner (the Protagonist) to construct his arguments? Or does cooperation amount to nothing more than abiding by certain basic rules, such as the pragma-dialectical rules for critical discussion? Or something in between? 
One way to go about this is to say that the answer will differ for various types of dialogue: persuasion dialogue, negotiation, eristics, inquiry, deliberation, information-seeking dialogue, and their subtypes and mixed types (Walton and Krabbe 1995). This is a route that would be in accord with the New Dialectic (Walton 1998) in which the types of dialogue are studied in detail ${ }^{15}$. Each type or subtype of dialogue could be assigned in the corresponding normative model its appropriate level of cooperativeness: this could be high for the information-seeking, inquiry and deliberation types, medium for persuasion dialogue and negotiation, and much lower for eristics. After all, the latter three types of dialogue start from a kind of conflict or difference of opinion, which naturally leads to competition, whereas the others do not.

But perhaps we should not aspire to have separate models for each type of dialogue, but rather to have just one model for argumentative exchanges, whether these occur in a context of persuasion, of negotiation, or of inquiry, or of any other type of dialogue. In that case, we must provide for a normative balance between cooperation and competition that holds for argumentative exchanges in all contexts. So, once more the question arises about how much cooperation and how much competition one should have. And what should be our primary concern? Cooperation or competition?

If competition prevails, the extreme case will be a kind of homo homini lupus-model, a model in which either discussant distrusts and tries to trip up the other. This would perhaps do as a model of argumentative exchange in eristic dialogue, but not as one of such exchanges in other types of dialogue. It may have its uses, but it is not what I envisage as a dialectical ideal model. Extreme cooperation, on the other hand, would make the model unsuitable for application to real life situations (it would fail to give relevant normative advice).

Probably, the best way would be to let cooperation prevail, but to take competitive aspects into account, either as features that function in the cooperative procedure itself - such as the division of roles (Questioner and Answerer, or Protagonist and Antagonist) - or as kinds of tactics that are permissible to an extent prescribed by the model. This latter route has been taken by the integrated pragma-dialectical theory. There the parties, ideally, behave largely cooperatively within the constraints of the standard model of critical discussion (which is only moderately competitive), but they can, by strategic maneuvering, express their competitive inclinations within these constraints. Present research in pragma-dialectics concerns precisely the ways this competitive aspect can be realized in various contexts. ${ }^{16}$

Here I would like to remark in passing that the standard model of critical discussion does not prescribe more cooperativeness than is needed for resolution of a difference of opinion on the merit. This is the common task. What would happen if other common tasks were added? Goals that pertain to inquiry, such as finding the best arguments for either side, or goals that pertain to the practical need to reach a decision about some action within a limited period of time, or goals that pertain to

15 The types of dialogue must here be conceived as activity types (Van Eemeren and Houtlosser 2005). See also Krabbe and Van Laar 2007: Section 3.1. The level of cooperativeness of a normative model depends on the activity type (type of dialogue) for which the model is to be a model.

16 See, for instance, Van Eemeren and Houtlosser (eds.) 2006, and Van Eemeren (ed.) 2008. 
teaching practices? In such cases the standard of cooperativeness will be set higher, and the room for strategic maneuvering will be restricted, but even so the concept of strategic maneuvering will not be essentially different. Such developments would, however, lead to a diversification of the one model for argumentative exchanges, and thus get close to the preceding option: that of having different models for different types of dialogue.

There is a third way to handle the balance between cooperative and competitive aspects: this is to have one complex model that consists of two or more subordinated models, each subordinated model having its own kind of balance between cooperation and competition. This third approach can be combined with the other two approaches by (1) introducing such complex models separately for each type of dialogue where this seems appropriate, and (2) leaving room for strategic maneuvering in the subordinated models and in the transitions between the subordinated models.

An example of such a complex model is the model of complex persuasion dialogue presented by Douglas Walton and myself (Walton and Krabbe 1995, Section 4.5). Here the subordinated models are a model of permissive persuasion dialogue (which is the overarching type of dialogue) and a model of rigorous persuasion dialogue (which is embedded in the former model of dialogue). The names of these subordinated models refer to the permissiveness or the lack of permissiveness of the rules, but in this book the more permissive rules pertain to a more cooperative kind of dialogue and the more rigorous rules to a more competitive. This is not a necessary connection, since rules

could also be permissive by admitting more competition. But all the same, the kind of complex dialogue Walton and I used to illustrate an embedding of rigorous dialogue in permissive dialogue can also be used to illustrate an embedding of competitive in cooperative dialogue. For more details, I refer to the book.

To sum up: there is more than one way to handle the tension between cooperativeness and competitiveness when constructing normative models for argumentative exchanges. Three routes can clearly be distinguished: that of having separate models for different types of dialogue, that of having one largely cooperative model that leaves room for competitive behavior (strategic maneuvering) and that of having models in which more cooperative and more competitive tasks are assigned to subordinated models. There is no reason to think that is all.

\section{Acknowledgement:}

I wish to thank Jan Albert Van Laar for useful comment on this paper. 


\section{REFERENCES}

ARISTOTLE (1976), Topica, in [Aristotle:] Posterior Analytics, Topica, translated by E. S. Foster, Cambridge, MA: Harvard University Press, and London: William Heinemann. First edition in 1960 (The Loeb Classical Library 391).

BARTH, Else M., and KRABBE, Erik C. W. (1982), From Axiom to Dialogue: A Philosophical Study of Logics and Argumentation, Berlin and New York: Walter de Gruyter.

BURKE, Kenneth (1950), A Rhetoric of Motives, New York: Prentice-Hall.

COHEN, Daniel H. (1995), "Argument is War... and War is Hell: Philosophy, Education, and Metaphors for Argumentation", Informal Logic: Reasoning and Arguing in Theory and Practice, 17 (2), pp. 177-188.

GOVIER, Trudy (1999), Philosophy of Argument, edited by John Hoaglund with a preface by John A. Blair, Newport News, Virginia: Vale Press.

HAMBLIN, Charles L. (1970), Fallacies, London: Methuen. Reprinted with a preface by John Plecnik and John Hoaglund, Newport News, Virginia: Vale Press, 1986.

KRABBE, Erik C. W. (2002), "Meeting in the House of Callias: An Historical Perspective on Rhetoric and Dialectic", in Frans H. van Eemeren and Peter Houtlosser (eds.), Dialectic and Rhetoric: The Warp and Woof of Argumentation Analysis, Dordrecht: Kluwer, pp. 29-40.

-_(2003), "Metadialogues", in Frans H. van Eemeren, J. Anthony Blair, Charles A. Willard and A. Francisca Snoeck Henkemans (eds.), Proceedings of the Fifth International Conference of the International Society for the Study of Argumentation, Amsterdam: Sic Sat, pp. 641644. Also published in Frans H. van Eemeren, J. Anthony Blair, Charles A. Willard and A. Francisca Snoeck Henkemans (eds.), Anyone Who Has a View: Theoretical Contributions to the Study of Argumentation, Dordrecht: Kluwer (Argumentation Library 8), pp. 83-90.

--(2004), "Strategies in Dialectic and Rhetoric", in Hans V. Hansen, Christopher W. Tindale, J. Anthony Blair, Ralph H. Johnson and Robert C. Pinto (eds.), Argumentation and its Applications: Proceedings from the Conference of the Ontario Society for the Study of Argumentation, May 17-19, 2001, University of Windsor, ON (CD-ROM), Windsor, ON: OSSA.

-(2007), "Predicaments of the Concluding Stage", in Hans V. Hansen, Christopher W.

Tindale, J. Anthony Blair, Ralph H. Johnson and David M. Godden (eds.), Dissensus and the Search for Common Ground: Proceedings of the Seventh Conference of the Ontario Society for the Study of Argumentation, June 6-9, 2007, University of Windsor, ON (CD-ROM), Windsor, ON: OSSA.

KRABBE, Erik, and VAN LAAR, Jan Albert (2007), "About Old and New Dialectic: Dialogues, Fallacies, and Strategies", Informal Logic: Reasoning and Arguing in Theory and Practice, 27 (1), pp. 27-58.

LAVERY, Jonathan (2007), "Plato's Protagoras: Negotiating Impartial Common Standards of Discourse", in Hans V. Hansen, Christopher W. Tindale, J. Anthony Blair, Ralph H. Johnson and David M. Godden (eds.), Dissensus and the Search for Common Ground: Proceedings of the Seventh Conference of the Ontario Society for the Study of Argumentation, June 6-9, 2007, University of Windsor, ON (CD-ROM), Windsor, ON: OSSA.

LORENZEN, Paul (1960), "Logik und Agon", in Atti del XII Congresso Internazionale di Filosofia (Venezia, 12-18 Settembre 1958), IV: Logica, linguaggio e comunicazione, Firenze: Sansoni, pp. 187-194. Reprinted in Lorenzen P., and Lorenz Kuno (1978), pp. 1-8.

_-_(1961), “Ein dialogisches Konstruktivitätskriterium”, in Infinitistic Methods: Proceedings of the Symposium on Foundations of Mathematics, Warsaw, 2-9 September 1959, Oxford: Pergamon Press; Warsaw: Panstwowe wydawnictwo naukowe, pp. 193-200. Reprinted in Lorenzen P., and Lorenz, Kuno (1978), pp. 9-16.

LORENZEN, Paul, and LORENZ, Kuno (1978), Dialogische Logik, Darmstadt: Wissenschaftliche Buchgesellschaft. 
MAKAU, Josina M., and MARTY, Dabian L. (2001), Cooperative Argumentation: A Model for Deliberative Community, Long Grove, IL: Waveland Press.

PLATO (1997), Complete Works, edited by John M. Cooper and D. S. Hutchinson, Indianapolis, IN, and Cambridge, MA: Hackett Publishing Company.

VAN EEMEREN, Frans H. (ed.) (2008), Strategic Maneuvering in Institutional Contexts: Dedicated to Peter Houtlosser (1956-2008), Special Issue of Argumentation: An International Journal on Reasoning, 22 (3).

VAN EEMEREN, Frans, and GROOTENDORST, Rob (1984), Speech Acts in Argumentative Discussions: A Theoretical Model for the Analysis of Discussions Directed Towards Solving Conflicts of Opinion, Dordrecht and Cinnaminson, NJ: Foris.

(2004), A Systematic Theory of Argumentation: The Pragma-Dialectical Approach, Cambridge: Cambridge University Press.

VAN EEMEREN, Frans, and HOUTLOSSER, Peter (1999), "Delivering the Goods in Critical Discussion", in Frans H. van Eemeren, Rob Grootendorst, J. Anthony Blair and Charles A. Willard (eds.), Proceedings of the Fourth International Conference of the International Society for the Study of Argumentation, Amsterdam: Sic Sat, pp. 168-177.

-(2002), "Strategic Manoeuvring in Argumentative Discourse: A Delicate Balance", in Frans H. van Eemeren and Peter Houtlosser (eds.), Dialectic and Rhetoric: The Warp and Woof of Argumentation Analysis, Dordrecht: Kluwer Academic, pp. 131-159.

(2005), "Theoretical Construction and Argumentative Reality: An Analytical Model of Critical Discussion and Conventionalised Types of Argumentative Activity", in David Hitchcock (ed.), The Uses of Argument: Proceedings of a Conference at McMaster University, Hamilton: Ontario Society for the Study of Argumentation, pp. 75-84.

- (eds.) (2006), Perspectives on Strategic Maneuvering, special issue of Argumentation: An International Journal on Reasoning, 20 (4).

WALTON, Douglas N. (1998), The New Dialectic: Conversational Contexts of Argument, Toronto: University of Toronto Press.

WALTON, Douglas, and KRABBE, Erik C. W. (1995), Commitment in Dialogue: Basic Concepts of Interpersonal Reasoning, Albany, NY: State University of New York Press.

WENZEL, Joseph W. (1987), “The Rhetorical Perspective on Argument”, in Frans H. van Eemeren, Rob Grootendorst, J. Anthony Blair and Charles A. Willard (eds.), Argumentation: Across the Lines of Discipline: Proceedings of the Conference on Argumentation 1986, Dordrecht and Providence, RI: Foris Publications, vol. 3, pp. 101-109.

WLODARCZYK, Marta (2000), "Aristotelian Dialectic and the Discovery of Truth", Oxford Studies in Ancient Philosophy, 18, pp. 153-210. 
(Página deixada propositadamente em branco) 

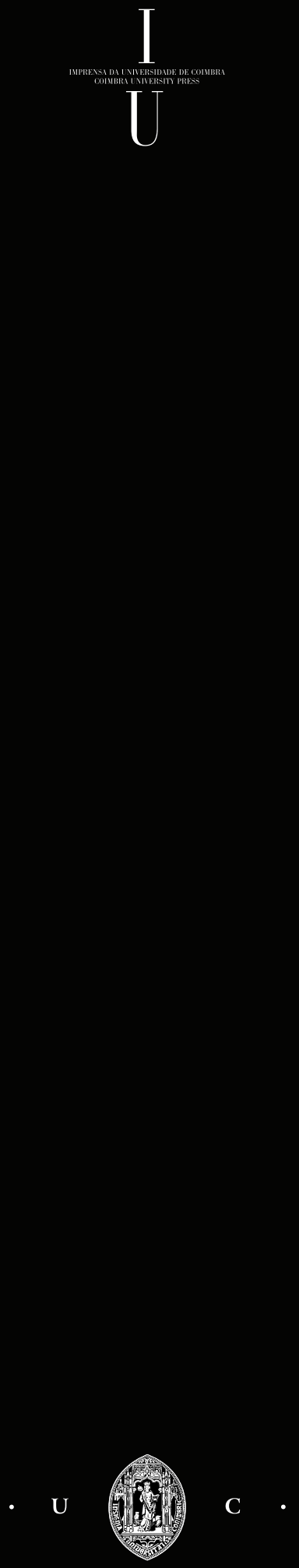